\title{
ОСОБЛИВОСТІ ВПРОВАДЖЕННЯ Е-МЕДИЦИНИ В УМОВАХ ДЕРЖАВНО-ПРИВАТНОГО ПАРТНЕРСТВА
}

\author{
Н. О. Сінєнко ${ }^{1}$, Г. В. Загорій, С. І. Мохначов \\ Національна медична академія післядипломної освіти імені П. Л. Шупика \\ ${ }^{1}$ Національна академія державного управління при Президентові України
}

\begin{abstract}
Розглянуто можливості та реальність вирішення завдань е-медицини за допомогою технологій державно-приватного партнерства (ДПП). Показано, що застосування технологій е-медицини $є$ одним з найважливіших важелів підвищення якості надання медичної допомоги населенню України. Беручи до уваги, що інформатизація охорони здоров'я $є$ надзвичайно коштовним проектом, її швидка реалізація можлива за умови максимально широкого ДПП. Вважається, що мобільна медицина являє собою найкращий приклад сучасного ДПП. Постулюється, що для ефрективного контролю якості надання медичної допомоги населенню мають бути створені спеціалізовані експертні та консультативно-дорадчі механізми в спеціалізованій системі органів державного контролю нової системи електронної системи охорони здоров'я зі строго визначеними принципами: об'єктивності, комплементарності, законності
\end{abstract}

Ключові слова: е-медицина, державно-приватне партнерство, інформатизація охорони здоров'я, медичні інформаційні системи, т-медицина, мобільний медичний електронний паспорт, нормативно-правове забезпечення е-медицини.

\section{ОСОБЕННОСТИ ВНЕДРЕНИЯ Е-МЕДИЦИНЫ В УСЛОВИЯХ ГОСУДАРСТВЕННО-ЧАСТНОГО ПАРТНЕРСТВА}

\author{
Н. А. Синенко ${ }^{1}$, Г. В. Загорий, С. И. Мохначев \\ Национальная медицинская академия последипломного образования имени П. Л. Шупика \\ ${ }^{1}$ Национальная академия государственного управления при Президенте Украины
}

\begin{abstract}
Рассмотрены возможности и реальность решения задач е-медицины с помощью технологий государственночастного партнерства (ГЧП). Показано, что применение технологий е-медицины является одним из важнейших рычагов повышения качества оказания медицинской помощи населению Украины. Принимая во внимание, что информатизация здравоохранения является чрезвычайно дорогостоящим проектом, ее быстрая реализация возможна при условии максимально широкого ГЧП. Подчеркивается мысль, что мобильная медицина представляет собой лучший пример современного ГЧП.

Постулируется, что для эффрективного контроля качества оказания медицинской помощи населению должны быть созданы специализированные экспертные и консультативно-совещательные механизмы в специализированной системе органов государственного контроля новой системы электронного здравоохранения со строго определенными принципами: объективности, комплементарности, законности и тому подобное.
\end{abstract}

Ключевые слова: е-медицина, государственно-частное партнерство, информатизация здравоохранения, медицинские информационные системы, m-медицина, мобильный медицинский электронный паспорт, нормативно-правовое обеспечение е-медицины. 


\title{
FEATURES OF E-MEDICINE INTRODUCTION IN THE PUBLIC-PRIVATE PARTNERSHIP
}

\author{
N. O. Sinyenko', G. V. Zagoriy, S. I. Mokhnachov \\ Shupyk National Medical Academy of Postgraduate Education \\ ${ }^{1}$ National Academy for Public Administration under the President of Ukraine
}

\begin{abstract}
It was discussed the possibilities and the reality of the e-medicine challenges through technology of public-private partnership (PPP). It is shown that the use of e-medicine is one of the most important levers of improving the quality of medical care in Ukraine. Taking into account that the computerization of health care is extremely expensive project its rapid implementation is possible for the widest possible PPP. It is believed that mobile medicine is the best example of modern PPP. It is postulated that for the effective control of the quality of medical care it should be created specialized expertise and advisory mechanisms in a specialized system of state control of the new system of electronic health systems with strictly defined principles such as objectivity, complimentarily, law and so on.
\end{abstract}

Key words: e-medicine, public-private partnership, health informatization, medical information systems, m-medicine, mobile electronic medical passport, e-medicine regulatory support.

Вступ. На рівні «політики мереж» інформаційнокомунікаційні технології являють собою нові форми політичної комунікації, що спрощують доступ до інформації та забезпечують прозорість політичних і парламентських процесів. Крім того, інтерактивні служби та управлінські процеси можуть і повинні все більше ставати доступними громадянам в оперативному мережному режимі. Прямий діалог із громадянами, електронне спілкування 3 населенням обумовлюють великі очікування від нових технологій розвитку демократії. Зазначені нові політичні процеси в суспільстві отримали назву «електронна демократія» (е-демократія) або «електронне керівництво» (е-керівництво).

Сучасні інформаційно-комунікаційні технології дозволяють модернізувати навіть (чи в першу чергу) державне управління так, щоб послуги держави надавалися громадянам самим дружнім чином. Вони знаходять саме широке розповсюдження в усьому світі. Так, на всесвітній виставці «Ехро 2000» канцлер ФРН Г. Шредер оголосив про запуск федеральної цільової програми «Bund Online 2005» («Союз на зв'язку 2005») в рамках електронного уряду Німеччини. Метою програми було надання близько 450 послуг федерального уряду громадянам і бізнесу через Інтернет $[3,16]$. Успіх проекту дозволив об'єднати електронні уряди всіх рівнів влади Німеччини та затвердити програму «Deutschland Online» («Німеччина на зв'язку», www.deutschland-online.de). Саме інформаційні «послуги» наочно демонструють, в яких складових життя громадян та існування бізнесу відсутні дійсно необхідні електронні послуги. Скоординований і уніфікований підхід до розробки послуг електронних урядів перерахованих трьох рівнів дуже бажаний, оскільки дозволяє компенсувати великий дефіцит робочої сили через автоматизацію ділових процесів. У час розвитку інформаційного суспільства, що базується на знаннях, громадяни i бізнес очікують від органів влади появи таких же різноманітних електронних послуг, які вони мають у страховому та банківському секторах.

Світова спільнота зацікавлена у стимулюванні інформаційних процесів і створенні національних стратегій формування інформаційного суспільства в кожній країні, незалежно від рівня їі економічного розвитку, за критеріями суспільства індустріального [15]. В Україні в останній час виконано велику кількість систематизованих досліджень щодо державно-приватного партнерства (ДПП) та його використання в сфері охорони здоров'я, науці, освіті $[6,10]$.

Мета роботи: розглянути можливість та реальність рішення завдань електронної медицини (е-медицини) за допомогою технологій ДПП.

Результати та їх обговорення. Інформатизація охорони здоров'я в Україні уявляється нами як проект, що складається з декількох стратегічних задач. Це, по-перше - створення розвиненого комунікаційного середовища з єдиним центром збору медичної інформації та розгалуженими на території України регіональними банками даних медичної інформації; по-друге - створення медичної інформаційної системи (МIC) 3 підсистемою ситуаційного моніторингу й управління підсистемою захисту інформації; втретє - створення мобільного медичного електронного паспорту (МЕП). Проблеми створення МІС детально розроблені, частково мають український пріоритет та викладені в концепції інформатизації охорони здоров'я [1]. 
Інформатизація сфери охорони здоров'я повинна суттєво підвищити ефективність діяльності Міністерства охорони здоров'я України за такими напрямами:

- підвищення ефективності збору, оброблення та зберігання медичної інформації за рахунок оптимізації потоків даних, структури та функціонального складу прикладних автоматизованих інформаційних підсистем;

- прискорення підготовки та підвищення рівня обгрунтування й якості рішень, що приймаються лікарем, за рахунок впровадження сучасних технологій та за підтримки багатофункціональних банків знань в реальному масштабі часу в єдиному інформаційному просторі з використанням сучасних телекомунікацій;

- підвищення ефективності праці лікарів за рахунок впровадження електронного документообігу з тотальною системою контролю виконавчої дисципліни та можливістю доступу до будь-яких інформаційних ресурсів МIC у межах наданих через єдиний інтерфейс прав;

- оптимізація ресурсів MIC за рахунок впровадження централізованих підсистем управління процесами лікування, персоналом, проектами тощо;

- підвищення рівня безпеки інформації, що циркулює в МIC, за рахунок централізації управління процесами моніторингу стану об'єктів та зовнішнього середовища;

- підвищення рівня підготовки та перепідготовки медичних працівників за рахунок застосування технологій дистанційного навчання та телемедицини.

Основним інструментом інтеграції різних підсистем у межах MIC за підтримки технічних засобів інформаційної безпеки служить підсистема електронного документообігу Такий підхід дозволяє зафіксувати відповідальність конкретних посадових осіб за надану в МIC інформацію та вклад кожної особи в процеси проведення лікувальних заходів, прийняття рішень і контролю за їх виконанням.

Основними принципами створення та побудови інформаційної системи МЕП вважаємо:

- зберігання медичної (соціальної) інформації про пацієнтів різних форматів, а також автоматичне виділення об'єктів, визначення якісних та кількісних характеристик з подальшою їх ідентифікацією, класифікація за допомогою систем розпізнавання образів;
- система повинна забезпечувати конфіденційність, цілісність і доступність інформації, що зберігається, з використанням сучасних засобів телекомунікації та електронного цифрового підпису;

- система має створюватися як національна, що охоплює все населення країни.

Бази даних, де зберігається інформація про пацієнтів, мають пройти державну реєстрацію за встановленим порядком.

Система буде забезпечувати належний захист персональних і медичних даних пацієнтів, технологічної інформації про своє функціонування. Тобто комплексна система захисту інформації розробляється таким чином, щоб незалежно від наявності та правильності іiі функціонування забезпечувати належний захист інформації в інформаційних системах медичних закладів.

Пропонується, що відповідальність за впровадження та забезпечення захисту персональних та медичних даних покладається на пацієнта.

Медичні та персональні дані поза межами території, що контролюється адміністрацією медичного закладу, мають передаватися тільки у криптографічно захищеному вигляді.

В МIC також мають бути передбачені методика і процедури переходу від ведення медичної картки у паперовому вигляді до застосування МЕП (перенесення медичних даних з паперових до електронних носіїв).

Кожна подія, що відбувається в інформаційній системі або МЕП з ініціативи особи (власника чи персоналу) чи процесу, має бути забезпечена підтвердженням авторства та фіксацією часу.

Медичні та персональні дані пацієнта, що обробляються в МIC, мають бути дзеркальним відображенням інформації, яка існує в МЕП. Підкреслимо, що основна місія МIC, 3 нашої точки зору, полягає в можливості отримання медичними працівниками валідної інформації про пацієнта вчасно та в повному обсязі. Для цього повинна постійно здійснюватися перевірка валідності, релевантності та пертинентності медичної інформації, що вноситься до інформаційної системи та МЕП. Також повинна забезпечуватися можливість моніторингу стану пацієнта, для чого МІС потребує спеціального програмного забезпечення.

Вкрай важливим $\epsilon$ питання формування медичної автоматизованої інформаційної системи для 
впровадження МЕП громадянина України у формі можливого ДПП.

В процесах інформатизації охорони здоров'я ДПП може бути реалізоване різними формами. Це, по перше, створення такого проекту, коли можливість безкоштовної реалізації логіки комп'ютеризації закладів охорони здоров'я компенсується платними інформаційними послугами хворим під час перебування в лікарні (інформаційні роз'яснення щодо ліків, застосованих під час лікування), а також після перебування в лікарні (видача довідок, супроводжувальних інформаційних матеріалів (рекомендацій щодо образу життя, гігієни, профілактичних ліків тощо). Це, по-друге, реалізація повного комплексу інформаційного супроводу пацієнтів - від довідкового сервісу до складних інформаційних технологій впровадження принципу другої думки, пошуку необхідних ліків, телемедицини тощо.

Другим прикладом застосування принципів ДПП для е-медицини, до того ж вкрай економічно зручним та вигідним для партнерів держави, може стати впровадження технології мобільної медицини (т-медицини), персоніфікованої медицини тощо.

Наведемо декілька прикладів. Клінічна дерматологія являє собою ідеальну модель для демонстрації ефективності використання е-медицини як 3 точки зору впровадження нових технологій, так i напрямків ДПП [17]. Серед напрямків е-медицини в дерматології - діагностика та моніторинг потенційно злоякісних і хронічних уражень шкіри на підгрунті об'єктивних даних. Проведення оцінки та моніторингу потенційно злоякісних уражень шкіри визначило високу чутливість і специфічність техніки теледермоскопії (teledermoscopy) $[12,13]$. Встановлена ефективність застосування смартфонів для моніторингу стану ран, зокрема у пластичній хірургії, для оцінки опіків і післяопераційних рубців. Переважно результати досліджень вказували на те, що медичні працівники неспеціалісти (наприклад, лікарі в навчальних закладах, медичні сестри, суміжні медичні працівники) після проходження мінімального додаткового навчання можуть виконувати нескладні завдання 3 отримання та аналізу зображень. Це $є$ суттєвою перевагою у наданні медичної допомоги в регіонах (сільські та віддалені), де відзначається нестача спеціалізованих кадрів.

Інша класична медична галузь застосування е-медицини - офтальмологія. Запис відео (чи фотографування) є суттєвим компонентом докумен- тування хірургічних і клінічних деталей [14]. Відеозаписи необхідні для передачі навичок, демонстрації нових процедур. Крім того, в загрозливих умовах застосування мобільних пристроїв сприяє своєчасній діагностиці та прискоренню управління лікування очних захворювань. Смартфони також досліджено як додаток до диспансеризації пацієнтів $з$ офтальмологічною патологією. Наявні комерційно доступні адаптери щілинної лампи, що забезпечують адекватну якість зображення в передній камері ока [18]. Оскільки в камерах смартфонів зображення щороку покращується, ймовірно, що в найближчому майбутньому виконана ними високоякісна картина очного дна стане підгрунтям для своєчасного направлення пацієнтів у високо спеціалізовану лікарню.

Якщо проаналізувати розуміння т-медицини в Україні, то переважно розуміють проект, спрямований на розвиток телемедицини шляхом інтеграції передового медичного досвіду та сучасних телекомунікаційних технологій. Основною метою вважають забезпечення доступною високо спеціалізованою медичною допомогою мешканців обласних центрів, а також пацієнтів, які приїжджають на консультацію до обласної лікарні з віддалених населених пунктів.

Важливо підкреслити, що т-медицина реально претендує на роль лідера в напрямку ДПП. Мобільні пристрої на кшталт смартфонів являють собою комерційний продукт, що потрібен населенню для виконання щоденних потреб. Медична ж складова може бути теоретично й практично безкоштовною та направлена на поліпшення здоров'я населення.

Підкреслимо, що, на жаль, нормативно-правового регулювання для т-медицини, як для е-медицини, розроблено недостатньо. Ця нормативна невизначеність перешкоджає розвитку інноваційних мобільних пристроїв та медичних програм і сповільнює їх впровадження у практику охорони здоров'я. Лікарі доки ще побоюються використовувати мобільні пристрої через страх, що ці медичні програми є ненадійними і не були перевірені.

Зрозуміло, що в такому разі мають бути створені спеціалізовані експертні та консультативно-дорадчі механізми в спеціалізованій системі органів державного контролю нової системи електронної системи охорони здоров'я 3 строго визначеними принципами.

Принции об'єктивності означає необхідність дотримуватися вимог об'єктивних закономірностей 
суспільного розвитку керуватися даними наукового аналізу управлінської ситуації, враховувати реальні можливості суб'єктів партнерської взаємодіiі, а також здійснювати постійний моніторинг і коригування реалізації проектів у межах ДПП.

Приници компліментарності конкретизується у принципах орієнтації на згоду, взаємної вигоди, спільної відповідальності і означає, що узгоджуючи навіть протилежні, на перший погляд, інтереси і йдучи на певні самообмеження, партнери досягають більшого результату, ніж кожен з них міг би досягнути самостійно.

Принции законності означає верховенство права, він спрямований на формування належного правового поля ДПП і обумовлює необхідність законодавчого визначення його засад. 3 принципом законності безпосередньо пов'язані принципи правової захищеності договірних умов ДПП і правової впорядкованості процесу його здійснення.

В основі принцину самоорганізації лежить здатність системи забезпечити адекватну реакцію на зовнішні впливи 3 метою досягнення своїх цілей, а також розуміння того факту, що партнерство $\epsilon$ однією 3 найбільш адекватних відповідей на сучасні виклики.

Нарешті, ДПП фактично неможливе за недотримання принципу соиіальної відповідальності, тобто відповідальності структур надання медичної допомоги за наслідки своєї діяльності, їхньої готовності брати на себе перед суспільством зобов'язання і виконувати їх.

На основі проведеного аналізу можна дійти висновку, що легальне визначення ДПП доцільно офіційно закріпити. Світова практика застосування такої форми співпраці дала змогу виділити низку характерних ознак ДПП, що зумовлюють доцільність їі використання на практиці та необхідність спеціального правового регулювання $[4,11]$ :

1) суспільна необхідність в реалізації складного та довгострокового проекту, для успішного здійснення якого державі чи територіальній громаді бракує можливостей, що й спонукає до встановлення ДПП;

2) участь у партнерстві принаймні двох сторін: одна 3 яких держава чи територіальна громада в особі уповноважених органів, друга - представник приватного бізнесу;

3) наявність у сторін ДПП спільної мети та чітко визначеного публічного інтересу певного рівня (загальнодержавного, регіонального, місцевого);
4) партнерський (рівноправний) характер взаємовідносин ДПП (хоча і 3 домінуванням в ДПП публічних інтересів, що компенсується приватному партнерові шляхом надання йому низки так званих гарантій в процесі реалізації проектів ДПП);

5) об'єднання активів, управлінського досвіду, інших ресурсів учасників ДПП;

6) опосередкування відносин ДПП через правові документи, насамперед, договори (контракти), які укладають на започаткування та в межах ДПП;

7) дотримання принципу справедливо сті при розподілі між сторонами ДПП ризиків та результатів функціонування партнерства;

8) необхідність захисту інтересів економічної конкуренції з метою попередження монополізації ринку, де узгоджено діють сторони ДПП, зловживань з боку приватних партнерів;

9) регулювання відносин ДПП за допомогою актів законодавства, що належать до різних правових інститутів (договірного права; корпоративного права; державного, зокрема антимонопольноконкурентного регулювання) та галузей права. Аналіз чинного Закону України «Про державноприватне партнерство» [2] та прийнятих відповідних актів законодавства дозволяе зробити висновок про врахування основних складових загальної технології ДПП, що напрацьована у світі, хоча і з одночасним ігноруванням інтересів економічної конкуренції.

Особливості українських форматів ДПП такі, що вони підтримують необхідність забезпечення більш високих техніко-економічних показників ефективності діяльності, ніж у разі її здійснення державним партнером без залучення приватного партнера; довготривалість відносин (від 5 до 50 років); передача приватному партнеру частини ризиків у процесі здійснення ДПП; внесення приватним партнером інвестицій в об'єкти ДПП 3 джерел, не заборонених законодавством. При цьому можливі будь-які сфери застосування ДПП, крім видів господарської діяльності, які можуть здійснювати виключно державні підприємства, установи та організації; основне спрямування проектів ДПП включає проектування, фінансування, будівництво, відновлення, експлуатацію, обслуговування, інші функції, пов'язані з виконанням укладених у рамках ДПП договорів [5, 7-9]. 
Таким чином, формування стратегічних цілей та векторів розвитку ДПП в Україні, особливо в рішенні одного 3 найактуальніших питань - інформатизації охорони здоров'я, полягає в їх ретельному обгрунтуванні та визначенні векторів розвитку цього феномена. У вирішенні першого завдання необхідно враховувати ряд моментів:

- функціональне призначення ДПП, що відбиває його фактичну й очікувану роль у соціальноекономічній системі України;

- реальний організаційно-економічний потенціал ДПП, підтверджений ефективною практикою його реалізації в зарубіжних країнах;

- наявність різних рівнів організації та функціонування ДПП (національний, регіональний), які відрізняються набором інваріантних і специфічних завдань його розвитку;

- різноманітність сфер організації та функціонування ДПП, що мають різні стартові умови і можливості його розвитку;

ся за інституційною природою та інтересами, реалізованими за його створення та функціонування.

3 метою ефективної реалізації Стратегічних цілей держави вважаємо за доцільне реорганізацію системи стратегічного управління в сфері інноваційного розвитку, створення чіткої ієрархії формування та реалізації документів стратегічного планування, що визначають державну політику в сфері науки й інновацій.

\section{Висновки.}

1. Застосування технологій е-медицини є одним iз важливіших важелів підвищення якості надання медичної допомоги населенню України.

2. Інформатизація охорони здоров'я в Україні здійснюється поступово як проект, що складається 3 декількох стратегічних завдань.

3. Враховуючи, що інформатизація сфери охорони здоров'я є надзвичайно коштовним проектом, його швидка реалізація можлива за умови максимально широкого державно-приватного партнерства.

4. Мобільна медицина є найкращим прикладом сучасного ДПП.

\section{Література.}

1. Концепція інформатизації охорони здоров'я України / О. П. Мінцер, Ю. В. Вороненко, Л. Ю. Бабінцева [та ін.] // Медична інформатика та інженерія. - 2012. - № 3. - C. 5-29.

2. Про державно-приватне партнерство : Закон України від 01.07.2010 № 2404-VI [Електронний ресурс] / база даних «Законодавство України»; офіційний веб-портал Верховної Ради України. - Режим доступу: http://zakon2. rada.gov.ua/laws/show/2404-17.

3. Про утворення міжвідомчої робочої групи 3 питань розвитку державно-приватного партнерства в Україні : наказ Міністерства економіки України 31.08.2010 № 1082 [Електронний ресурс] / сайт «Парус Інтернет-Консультант» Інформаційно-аналітична система по законодавству України. - Режим доступу: http:// cons.parus.ua/map/doc/06PVC46882/Pro-utvorennyamizhvidomchoyi-robochoyi-grupi-z-pitan-rozvitkuderzhavnoprivatnogo-partnerstva-v-Ukrayini.html.

4. Узунов Ф. В. Европейский опыт реализации государственно-частного партнерства и предпосылки развития в Украине / Ф. В. Узунов // Современный научный вестник. - 2013. - № 26, Т. 165. - С. 65-75.

5. Узунов Ф. В. Класифікація форм державно-приватного партнерства / Ф. В. Узунов // Інвестиції: практика та досвід. - 2013. - № 17. - С. 113-115.

6. Узунов Ф. В. Пріоритетні галузі розвитку державноприватного партнерства в Україні / Ф. В. Узунов // Інвестиції: практика та досвід. - 2013. - № 18. - С. 142-144. 7. Узунов Ф. В. Удосконалення механізмів державного управління в сфері державно-приватного партнерства / Ф. В. Узунов // Держава та регіони. - (Державне управління). - 2015. - № 2. - С. 131-134.

8. Узунов Ф. В. Формування концепції розвитку партнерських взаємовідносин держави, науки, освіти та бізнесу / Ф. В. Узунов // Наукові розвідки з державного та муніципального управління : зб. наук. пр. - 2014. Вип. 1. - С. 114-123.

9. Щодо розвитку державно-приватного партнерства як механізму активізації інвестиційної діяльності в Україні: Аналітична записка / сайт «Національного інституту стратегічних досліджень».-Режим доступу: http://www. niss.gov.ua/articles/816/\#_ftnl4.

10. Hammami M. Determinants of public-private partnership in infrastructure / M. Hammami, J. F. Ruhashyankiko, E. B. Yehoue - Washington : International Monetary Fund, 2006. - IMF Working Paper. - WP/06/99. - 37 p.

11. Mobile teledermatology for skin tumor screening: diagnostic accuracy of clinical and dermoscopic image teleevaluation using cellular phones / S. Kroemer, J. Fruhauf, T. M. Campbell [et al.] //Br. J. Dermatol. - 2011. - Vol. 5, No. 164. - P. 973-979.

12. Novel uses of smartphones in ophthalmology / R. K.Lord, V. A. Shah, A. N. San Filippo, R. Krishna // Ophthalmology. - 2010. - Vol. 117, No. 6. - P. 1274.e3. 
13. Public-private partnerships in infrastructure. Days 2008 / P. Saragiotis (ed.). - Washington: The International Bank for Reconstruction and Development, 2009. - 112 p.

14. Schaefer M. Germany: Public private partnerships in Germany - An overview [Electronic resource]/ M. Schaefer, T. Voland // Mondaq ${ }^{\circledR L t d . ~-~} 26$ November 2009. - Режим доступу: http://www.mondaq.com/article. asp? articleid $=87762$.

15. The effectiveness of mobile-health technologies to improve health care service delivery processes: a systematic review and meta-analysis / C. Free, G. Phillips, L. Watson [et al.] //PLoS medicine. - 2013. - Vol. 10, No. 1. - e1001363. 16. Validation of Near Eye Tool for Refractive Assessment (NETRA) - Pilot Study / A. Bastawrous, C. Leak, F. Howard, B. V. Kumar// journal of Mobile Technology in Medicine. - 2012. - Vol. 1, No. 3. - P. 6-16.

\section{References.}

1. Mintser, O. P., Voronenko, Yu. V., Babintseva, L. Yu., Banchuk, M. V., Krasnov, V. V., Martsenyuk, V. P., ... Shypiatskyi, I. M. (2012). Kontseptsiya informatizatsii okhoroni zdorov'ya Ukraini [Conception of informatization of healthcare of Ukraine]. Medichna informatika ta inzheneriya (Medical Informatics and Engineering), 3, 5-29. [in Ukrainian].

2. The Law of Ukraine No. 2404-VI (2010, 01 luly). Pro derzhavno-privatne partnerstvo [On the State Partnership]. ["Zakonodavstvo Ukraini" database]. Retrieved from http:// zakon2. rada.gov.ua/laws/show/2404-17 [in Ukrainian].

3. Order of the Ministry of Economy No. 1082 (2010, 31 august). Pro utvorennya mizhvidomchoi robochoi grupi z pitan' rozvitku derzhavno-privatnogo partnerstva $\mathrm{V}$ Ukraini [On the formation of the interdepartmental working group on the development of public-private partnership in Ukraine]. ["Parus Internet Consultant" information-analytical system on Ukrainian legislation]. Retrieved from http://cons.parus.ua/map/doc/06PVC46882/ Pro-utvorennya-mizhvidomchoyi-robochoyi-grupi-z-pitanrozvitku-derzhavnoprivatnogo-partnerstva-v-Ukrayini.html [in Ukrainian].

4. Uzunov, F. V. (2013). Evropeiskii opyt realizatsii gosudarstvenno-chastnogo partnerstva i predposylki razvitiya $v$ Ukraine [European experience in the implementation of public-private partnerships and the development of its conditions in Ukraine]. Sovremennyi nauchny ivestnik (The Modern Scientific Bulletin), 26(165), 65-75. [in Russian].

5. Uzunov, F. V. (2013). Klasifikatsiya form derzhavnoprivatnogo partnerstva [Classification of public-private partnership forms]. Investitsii: praktika ta dosvid (Investment: Practice and Experience), 17, 113-115. [in Russian].

6. Uzunov, F. V. (2013). Prioritetni galuzi rozvitku derzhavno-privatnogo partnerstva $v$ Ukraini [Priority sectors of public-private partnership in Ukraine]. Investitsii: praktika ta dosvid (Investment: Practice and Experience), 18, 142-144. [in Ukrainian],

7. Uzunov, F. V. (2015). Udoskonalennya mekhanizmiv derzhavnogo upravlinnya $\mathrm{v}$ sferi derzhavno-privatnogo partnerstva [Improving governance mechanisms in the field of public-private partnership]. Derzhava ta regioni (State and Regions). 2, 131-134. [in Ukrainian].

8. Uzunov, F. V. (2014). Formuvannya kontseptsii rozvitku partners'kikh vzayemovidnosin derzhavi, nauki, osviti ta biznesu [Formation of the concept of development of partnership relations between the state, science, education and business]. In Naukovi rozvidki z derzhavnogo ta munitsipal'nogo upravlinnya (Scientific research in the public and municipal administration): collection of scientific papers. Kyev : AMM. [in Ukrainian].

9. Shchodo rozvitku derzhavno-privatnogo partnerstva yak mekhanizmu aktivizatsii investitsiinoi diyal'nosti $\mathrm{v}$ Ukraini [With regard to the development of public-private partnerships as a mechanism to stimulate investment activity in Ukraine]. Analytic note. (n. d.). [The National Institute for Strategic Studies]. Retrieved from http://www.niss.gov. ua/articles/816/\#_ftnl4 [in Ukrainian].

10. Hammami, M., Ruhashyankiko, 1. F. \& Yehoue, E. B. (2006). Determinants of public-private partnership in infrastructure. Washington: International Monetary Fund.

11. Kroemer, S., Friihauf, 1., Campbell, T. M, Massone, C, Schwantzer, G, Soyer, H. P. \& Hofmann-Wellenhof, R. (2011). Mobile teledermatology for skin tumour screening: diagnostic accuracy of clinical and dermoscopic image teleevaluation using cellular phones. Br. 1. Dermatol., 5(164), 973-979. doi: 10.1111/j.1365-2133.2011.10208.

12. Lord, R. K., Shah, V. A., San Filippo, A. N. \& Krishna, R. (2010). Novel uses of smartphones in ophthalmology. Ophthalmology, 117(6), 1274-e3. doi: 10.1016/j.ophtha.2010.01.001.

13. P. Saragiotis (ed.). Public-private partnerships in infrastructure. Days 2008 (2009). Washington : The International Bank for Reconstruction and Development.

14. Schaefer M. \& Voland T. (2009, 26 November). Germany: Public private partnerships in Germany - An overview. Retrieved from http://www.mondaq.com/article. asp? articleid $=87762$.

15. Free, C., Phillips, G., Watson, L., Galli, L., Felix, L., Edwards, P., ... Haines, A. (2013). The effectiveness of mobile-health technologies to improve health care service delivery processes: a systematic review and meta-analysis. PLoS medicine, 10(1), el001363. doi: 10.1371/journal. pmed.1001363.

16. Bastawrous, A., Leak, C., Howard, F. \& Kumar B. V. (2012). Validation of Near Eye Tool for Refractive Assessment (NETRA) - Pilot Study, lournal of Mobile Technology in Medicine, 1(3), 6-16. doi:10.7309/jmtm,17. 